\title{
Resisting change: The influence of luminance changes on visual marking and the preview benefit
}

\author{
DERRICK G. WATSON \\ University of Warwick, Coventry, England \\ AND \\ Jason J. BraithWAite AND GLYN W. Humphreys \\ University of Birmingham, Birmingham, England
}

\begin{abstract}
Visual search can benefit when one set of distractors is presented as a preview, prior to the appearance of the second set of distractors plus the target (Watson \& Humphreys, 1997). It has been shown that changing the shape of the old, previewed stimuli when the new items appear causes the old stimuli to recompete for selection with the new ones. In contrast, changing the luminance or color of the old stimuli has no detrimental effects. Here, we present five experiments that reassessed the effect of luminance changes in preview search. We show (1) that preview search is remarkably resistant to large changes in the absolute luminance of the old stimuli, even when those changes would ordinarily be sufficient to signal the appearance of a new object and draw attention (Experiments 1 and 2), and (2) that resistance to luminance changes can be bolstered by feature-based inhibitory processes (Experiments 3-5). These findings are discussed in terms of the possible ecological properties of time-based visual selection and possible mechanisms underlying the preview benefit.
\end{abstract}

The limitations of visual processing are well-known and encountered frequently in our everyday activities. Put simply, in most situations, we are presented with much more visual information than we are able to process. Given this fact, for behavior to be efficient and adaptive, we need mechanisms that enable us to prioritize only the information most relevant to our current goals, as well as to discard other information that is irrelevant at the current time. One way to select information is to concentrate processing at the location of the relevant information. For example, we might focus attention at the location of a traffic signal to detect when it changes to green. However, in many situations, this type of spatial selection (Downing \& Pinker, 1985; Eriksen \& St. James, 1986; Kawahara \& Yamada, 2006; Kramer \& Hahn, 1995; Posner, 1980; Yantis \& Jonides, 1990) will not work - for example, when we do not know where in the field the important information will appear. In such ambiguous situations, it would be useful to give priority to newly appearing information over that already present.

Previous research has shown that the abrupt appearance of a new perceptual object among a field of already present but changing items automatically captures attention (e.g., Davoli, Suszko, \& Abrams, 2007; Yantis \& Jonides, 1984). This occurs even when the new object is no more likely to be the target than are any of the changing items, and irrespective of whether or not the new object is ac- companied by a transient luminance change (Yantis \& Hillstrom, 1994). However, such automatic capture and attentional prioritization appear to be limited to around only three or four items; beyond this point, all items, both old and new, appear to compete equally for attention (Yantis \& Johnson, 1990; Yantis \& Jones, 1991).

\section{Intentional Time-Based Selection: Visual Marking}

In contrast to the work of Yantis and colleagues, Watson and Humphreys (1997) examined situations in which observers intentionally tried to prioritize newly appearing stimuli and to ignore distracting stimuli already in the field (see also Kahneman, Treisman, \& Burkell, 1983). In their preview condition, Watson and Humphreys (1997) presented participants with a search display in which one set of distractors (green "H"s) appeared $1 \mathrm{sec}$ before the remaining distractors (blue "A"s) and the target (a blue "H"). Thus, the final display formed a conjunction search task (Treisman \& Gelade, 1980), which typically produces inefficient search, as signaled by a steep response time (RT)-display size function (i.e., there is a steep search slope; see Wolfe, 1998, for an overview). This preview condition was compared with two baselines. In the fullelement baseline (FEB) condition, all of the items appeared simultaneously, so there was no preview of one set of distractors. In the half-element baseline (HEB) condi-

D. G. Watson, d.g.watson@warwick.ac.uk 
tion, only the second set of items from the preview search condition was presented (blue "A"s and, when present, a blue "H" target). The idea was that if participants could successfully ignore old items, search should be as efficient in the preview as in the HEB condition, when only the new elements from the preview condition were presented. In contrast, if the old previewed items could not be suppressed, search should then be no more efficient than in the FEB condition, when all items appeared at once.

The results showed that search performance in the preview condition was much more efficient than in the FEB condition (the preview benefit) and was not reliably different from performance in the HEB. This suggests that participants could fully ignore the old items and focus their attention (restrict their search) to just the new items. In contrast to the findings for automatic new-object capture (see above), the preview benefit is effective for more than 3-4 new items; Jiang, Chun, and Marks (2002a) later demonstrated that up to 30 old items can be ignored. Following additional experiments, Watson and Humphreys (1997) proposed that participants actively inhibited the old previewed stimuli in order to maximize an attentional advantage for the new items (for an overview, see Watson, Humphreys, \& Olivers, 2003; see also Donk, 2005, 2006; Donk \& Theeuwes, 2001, 2003; and Jiang, Chun, \& Marks, 2002b, for alternative suggestions). They proposed that the suppression process was resource demanding and was based on the online development and maintenance of a template that coordinated inhibition of the old items. Watson and Humphreys (1997) termed this process visual marking.

Several more recent findings have supported this account. For example, (1) it takes a relatively long time before old luminance-defined items can be effectively ignored (Braithwaite, Humphreys, Hulleman, \& Watson, 2007; Humphreys, Olivers, \& Braithwaite, 2006; Humphreys, Stalmann, \& Olivers, 2004; Watson \& Humphreys, 1997); ${ }^{1}$ (2) the preview benefit can be disrupted by attentionally demanding competing tasks present during the preview period (Braithwaite, Humphreys, Watson, \& Hulleman, 2005; Humphreys, Watson, \& Jolicœur, 2002; Watson \& Humphreys, 1997); (3) probe dots are harder to detect when they appear at the locations of old items, but only when participants are intentionally trying to suppress the old stimuli (Agter \& Donk, 2005; Braithwaite \& Humphreys, 2007; Braithwaite, Humphreys, \& Hulleman, 2005; Humphreys, Stalmann, \& Olivers, 2004; Watson \& Humphreys, 2000); and (4) a prior presentation of the old items can positively impact the establishment of a preview benefit (Kunar \& Humphreys, 2006; Kunar, Humphreys, \& Smith, 2003a; Kunar, Shapiro, \& Humphreys, 2006). Early experiments suggested that the suppression of stationary stimuli was achieved by location-based inhibition, whereas the suppression of moving items occurred via feature-based inhibition (Kunar, Humphreys, \& Smith, 2003b; Olivers, Watson, \& Humphreys, 1999; Watson \& Humphreys, 1998). However, more recent work has provided evidence for feature-based inhibition sometimes being involved in suppressing stationary stimuli (Braithwaite \& Humphreys, 2003, 2007; Braithwaite, Humphreys, \& Hodsoll, 2003, 2004; Braithwaite et al., 2007; Olivers \& Humphreys, 2003; for an overview, see Olivers, Humphreys, \& Braithwaite, 2006) and for location-based components being involved in suppressing moving stimuli (Watson, 2001).

\section{The Effects of Visual Change on Previewed Distractors}

Although there is evidence for a top-down component in preview search (see, e.g., Humphreys et al., 2002), the preview benefit is modified in a bottom-up manner by certain changes in the ignored stimuli. For example, Watson and Humphreys (2002) examined what happened if the old previewed items changed when the new were added. If visual marking is an ecologically adaptive mechanism, we might expect ignored objects to recompete for selection when ecologically important changes are made to themin other words, that their suppression would be lifted. Consistent with this idea, Watson and Humphreys (2002) found that shape changes to the old previewed items (a rightangle bracket changing to a letter " $H$ ") that occurred at the time new stimuli were added were sufficient to abolish the preview benefit. This indicates that the shape or identity change caused the old items to recompete for selection with the new stimuli (see also Watson \& Humphreys, 1997, for related findings). In contrast, if the old items underwent luminance or color changes (e.g., consistent with an environmental change such as a shadow passing over), the old items continued to be ignored, and a full preview benefit occurred (but see also Pratt, Theeuwes, \& Donk, 2007). These results held even when the overall variation in luminance in both the shape and luminance change conditions was matched with that in the shape change condition (see also Kunar, Humphreys, \& Smith, 2003b, for related findings with moving stimuli). Watson and Humphreys (2002) suggested that this pattern of results reflected the ecologically adaptive properties of visual marking. For example, changes in an ignored object's shape are likely to be behaviorally relevant, since they could indicate a change in the heading or gaze of a predator or the emergence of a previously camouflaged object. In contrast, changes in surface features, such as color or luminance, are likely to be much less important and could reflect simple changes in environmental illumination (e.g., a shadow passing).

Other work has examined the effects of irrelevant changes occurring while preview items are displayed and before the onset of the new search stimuli. Watson and Humphreys (2005) showed that the sudden appearance of irrelevant stimuli in the preview display, arriving just before the new stimuli, had no impact on preview search. However, if the irrelevant stimuli (1) appeared first with the old stimuli and then (2) disappeared during the preview interval only to (3) reappear with the new items, the preview benefit was disrupted but not abolished. Watson and Humphreys (2005) proposed that all of the initial stimuli (both the search-relevant and -irrelevant) were combined into the inhibitory template of the preview, and this template was disrupted by the disappearance of the irrelevant items during the preview period. Similarly, other results have shown that the preview benefit can be abolished by blinking the old previewed items off, but then back on when the new stimuli arrive (Kunar, Humphreys, Smith, 
\& Watson, 2003; Watson \& Humphreys, 1997). Here, again, the disappearance and reappearance of objects is disruptive to preview search, consistent with visual marking being ecologically adaptive (in this case, sensitive to the reappearance of a potential threat or opportunity).

\section{Is Luminance Change Sufficient to Induce Change to Preview Representations?}

Rauschenberger (2003) used a paradigm based on that of Folk, Remington, and Johnston (1992; see also Folk, Remington, \& Wright, 1994) to investigate whether sufficiently large luminance changes to existing objects would eventually be treated as signaling the emergence of a new object. As Rauschenberger stated, "it is reasonable to assume that there are limits to the magnitude of luminance change that the visual system will still regard as ecologically plausible" (p. 601). In other words, the visual system will at some point treat a sufficiently large luminance change as signaling the appearance of a new perceptual object that should attract attention, and it will no longer treat the change as a variation in lighting or the surface properties of an existing object. Rauschenberger compared the effectiveness in capturing attention of new-object, luminance change, and singleton cues. In the new-object condition, participants were first presented with eight outline boxes, some of which contained box figure- 8 premasks. One of the boxes was then cued by briefly presenting four small solid disks, one at each corner of the box. The premasks subsequently changed into letters, and at the same time a new letter (visual onset) appeared in one of the previously empty outline boxes. The task was to indicate whether a target letter " $\mathrm{H}$ " or "U" occurred concurrently with the distractor letters in the final display, with the target always being defined by a new object. The luminance change cue condition had essentially the same sequence of events, except that all of the outline boxes had disks at their four corners, and the cue consisted of briefly illuminating the disks surrounding one of the boxes. In the luminance singleton condition, disks were briefly presented around all of the outline boxes, and the cue consisted of one set of disks that was of higher luminance than the others.

The results showed that the new-object cue always captured attention, irrespective of whether the cuing disks were of high or low luminance $\left(1.3-14.8 \mathrm{~cd} / \mathrm{m}^{2}\right)$. In contrast, the singleton cue did not affect performance, suggesting that the "singleton" did not capture attention. However, most interestingly, cues with a large $\left(>50 \mathrm{~cd} / \mathrm{m}^{2}\right)$ but not a small $\left(<15 \mathrm{~cd} / \mathrm{m}^{2}\right)$ luminance increment did capture attention. Thus, the visual system appeared to treat a sufficiently large change in luminance in an already existing object as equivalent to the appearance of a new object at that location, thus leading to attention capture. Further experiments revealed that what was crucial for triggering a new-object response was the ratio of change rather than the absolute change. For example, in one experiment, the absolute change in luminance was held constant at about $51 \mathrm{~cd} / \mathrm{m}^{2}$, and ratio changes of $12.1,3.6$, and 2.5 were examined. The overall conclusion was that both appearances of new stimuli and changes to old stimuli need to be accompanied by a change in luminance ratio at least between 2.5 and 3.3 for those items to be treated as new perceptual objects.

\section{Purpose of the Present Study}

In the present article, we examine whether luminance changes on the order of those examined by Rauschenberger (2003) influence the preview benefit in the same way as they influence the new-object capture effect. Watson and Humphreys (2002) speculated that certain changes to previews (in luminance and color) do not eliminate the preview benefit because, in ecological terms, the changes are unlikely to be indicative of a behaviorally important change in the old stimulus. However, the ratio of luminance change tested by Watson and Humphreys (2002) was much less than the 1:3 change proposed by Rauschenberger as the criterion for the appearance of a new object (the change in their study represented a 1:1.90 luminance increase). Thus, the luminance change may simply have been insufficient to lead to perception of a new object. On this view, introducing a larger change in the luminance of the previewed items (on the order of the changes used by Rauschenberger, 2003) should eliminate the preview benefit, because the changed preview stimuli should be treated as new objects. On the other hand, if such large luminance changes remain consistent with ecological invariance in the same object, the preview benefit may prove to be relatively robust - even with change ratios sufficient to eliminate an onset benefit.

The present experiments also addressed different theoretical accounts of the preview benefit in search. Although we have discussed the preview benefit in terms of inhibitory visual marking, this is by no means the only account in the literature. One alternative, the temporal asynchrony account (Jiang, Chun, \& Marks, 2002b; Jiang \& Wang, 2004), maintains that the preview benefit arises because the old and new items appear at different times, and this time difference can be used to temporally group and segment the old from the new items. Following temporal segmentation, attention can be applied to either group, depending on the task demands. This account predicts that any manipulation that produces grouping between the old and new stimuli, rather than temporal segmentation, should reduce the ability to attend to either group selectively. In the present circumstances, increasing the luminance of the old items when the new are added should facilitate grouping between the old and new items (on the basis of common luminance increases), reducing the temporal asynchrony between them. This should hold true particularly when the luminance increase is sufficient to wipe out any luminancebased capture of attention (see Rauschenberger, 2003). As a consequence, the preview benefit should be reduced.

A second alternative is the new-object-onset account (Donk, 2005, 2006; Donk \& Theeuwes, 2001, 2003; Donk \& Verburg, 2004). According to this theory, the preview benefit arises because the abrupt luminance increments (caused by presenting the new objects) capture attention automatically (Davoli et al., 2007; Yantis \& Hillstrom, 1994; Yantis \& Johnson, 1990; Yantis \& Jones, 1991; Yantis \& Jonides, 1984; but see also Franconeri, Hollingworth, \& Simons, 2005; Jingling \& Yeh, 2007). Because of automatic 
capture of attention by the new onsets, only the new items influence search, and a preview benefit arises (e.g., in comparison with search within a full-set baseline, in which all of the items appear together). This proposal predicts that any changes in the old items that act to prevent capture by new onsets should abolish the preview benefit. According to the work of Rauschenberger (2003), this should arise when the old items receive a luminance increment greater than the 1:3 ratio required to eliminate onset capture.

We report five experiments here. In Experiments 1 and 2, we examined preview search when the old items underwent luminance changes substantially greater than the 1:3 ratio change reported by Rauschenberger (2003) as necessary to turn an old object into a new object. In Experiments 3 to 5 , we attempted to establish the boundary conditions for which luminance changes in old previewed items would be effective in reducing the preview benefit. By exploring these boundary conditions, we provided important new constraints on understanding the processes underlying preview search.

\section{EXPERIMENT 1 Two- and Fourfold Luminance Increments in Previewed Objects}

Experiment 1 investigated the influence on preview search of 1:2 and 1:4 increases in the luminance of the previewed distractors. The basic paradigm was similar to that of previous preview studies and included four conditions. In the two preview conditions, participants were first presented with green " $\mathrm{H}$ " distractors for $1,000 \mathrm{msec}$, followed by blue "A" distractors and a blue " $\mathrm{H}$ " target. When new blue items were added, the green " $H$ "s increased their luminance by either two or four times. These preview conditions were compared with two baselines, FEB and HEB. In the FEB, all of the display items appeared simultaneously, and in the HEB, only the new items from the preview conditions were presented. Importantly, the final displays in the preview conditions were equivalent to those in the respective baselines in terms of overall luminance and color differences.

\section{Method}

\section{Participants}

A total of 10 participants ( 9 female, 1 male), 18-33 years of age $(M=20.0)$, took part in this experiment. All were undergraduate students at the University of Warwick with normal or corrected-tonormal visual acuity.

\section{Stimuli and Apparatus}

Displays were presented on a 1-GHz Pentium-based PC attached to a 19 -in. (visible diagonal, $44 \mathrm{~cm}$ ) $60-\mathrm{Hz}$ Sony monitor, at a resolution of $800 \times 600$ pixels, by custom programs written in Turbo Pascal running in MS-DOS. Participants viewed the monitor at eye level from a distance of approximately $60 \mathrm{~cm}$, although no mechanical means were used to restrict head movements. The stimuli consisted of a blue " $\mathrm{H}$ " target and green " $\mathrm{H}$ " and blue "A" distractors. The values of the colors used, in terms of RGB and CIE $x y$, were as follows ${ }^{2}$ : standard blue-RGB $=68,164,176$; CIE $x y=0.212$, 0.286 ; luminance $=29.9 \mathrm{~cd} / \mathrm{m}^{2} ;$ standard green-RGB $=11,193$ 126; CIE $x y=0.245,0.462 ;$ luminance $=38.8 \mathrm{~cd} / \mathrm{m}^{2} ;$ medium green- $\mathrm{RGB}=9,149,97 ;$ CIE $x y=0.252,0.472 ;$ luminance $=$
$19.9 \mathrm{~cd} / \mathrm{m}^{2} ;$ dim green-RGB $=7,112,73 ;$ CIE $x y=0.262,0.488$; luminance $=9.3 \mathrm{~cd} / \mathrm{m}^{2}$. All stimuli were presented against the nonilluminated screen background $\left(0.49 \mathrm{~cd} / \mathrm{m}^{2}\right)$.

The stimuli were created from the segments of a box figure- 8 drawn with lines of a double-pixel width and measuring $7 \mathrm{~mm}$ in width $\times 9 \mathrm{~mm}$ in height overall. Each search display was generated by placing the stimuli into the cells of a $6 \times 6$ invisible grid with $25-\mathrm{mm}$ center-to-center spacing and then jittering the stimulus positions by up to \pm 15 pixels $(6.5 \mathrm{~mm})$ along the $x$ - and $y$-axes. The target could only ever appear in columns $1,2,5$, or 6 , in order to make its left or right position relative to the screen center unambiguous. The distractor stimuli were placed in the remaining cells, with the constraint that equal numbers of green and blue stimuli had to appear on each side of the display. Some catch trials were also included, which contained no target. Responses were made via the buttons on the left and right sides of a three-button custom-built response box interfaced to the computer's joystick/game port.

On all target-present trials, participants searched the display and indicated whether the target was on the left or right side of the display by pressing the corresponding button on the response box. On catch trials, there was no target present, and participants were told to make no response; after $4 \mathrm{sec}$, the next trial began automatically. This coarse target localization procedure allowed us to maximize the number of target-present trials, which are less ambiguous to interpret than target-absent trials (see, e.g., Chun \& Wolfe, 1996). Furthermore, the inclusion of catch trials ensured that participants had to search the entire display before responding (because the absence of a target on one side did not guarantee its presence on the other). Error feedback consisted of a $1000-\mathrm{Hz}$ tone that sounded for $500 \mathrm{msec}$. The preview benefit has been replicated on a number of occasions, using this procedure or other, similar forced choice response procedures (e.g., Allen, Humphreys, \& Matthews, 2008; Humphreys, Kyllingsbæk, et al., 2004; Olivers \& Humphreys, 2002).

\section{Design and Procedure}

There were four conditions: a half-element baseline (HEB), fullelement baseline (FEB), a 1:2 luminance change preview condition $\left(\mathrm{PRE}_{1: 2}\right)$, and a 1:4 luminance change preview condition $\left(\mathrm{PRE}_{1: 4}\right)$. A trial in the FEB consisted of a blank screen $(500 \mathrm{msec})$, followed by a central fixation $\operatorname{dot}\left(1.5 \mathrm{~mm}^{2}\right)$ for $1,000 \mathrm{msec}$. The search display followed, which consisted of 4, 8, or 16 items: The target was a blue " $H$ " $\left(29.9 \mathrm{~cd} / \mathrm{m}^{2}\right)$, and the distractors green "H"s $\left(38.8 \mathrm{~cd} / \mathrm{m}^{2}\right)$ and blue "A"s $\left(29.9 \mathrm{~cd} / \mathrm{m}^{2}\right)$. The display remained until the participant responded or until $4 \mathrm{sec}$ had elapsed, after which the next trial began. The HEB was essentially the same as the FEB, except that the green " $\mathrm{H}$ "s were not present. Hence, the display size for this baseline was 2,4 , or 8 items. In the preview conditions, the green " $H$ " distractors were initially presented for $1,000 \mathrm{msec}$, after which they increased in luminance at the same time that the blue stimuli were added. In the $\mathrm{PRE}_{1: 2}$ condition, the initial luminance of the green " $\mathrm{H}$ "s was $19.9 \mathrm{~cd} / \mathrm{m}^{2}$, which changed to $38.8 \mathrm{~cd} / \mathrm{m}^{2}$ when the blue items were added (a twofold increase in absolute luminance). In the $\mathrm{PRE}_{1: 4}$ condition, the luminance of the initial green "H"s was $9.3 \mathrm{~cd} / \mathrm{m}^{2}$, which then also changed to $38.8 \mathrm{~cd} / \mathrm{m}^{2}$ (a fourfold increase in absolute luminance) when the blue items were added. In both preview conditions, the task was to ignore the previewed distractors and select the new items. Note also that having the luminance of the blue items set to approximately $30 \mathrm{~cd} /$ $\mathrm{m}^{2}$ in all conditions meant that the absolute change in green " $\mathrm{H}$ " distractor luminance in the $\mathrm{PRE}_{1: 4}$ condition was approximately the same as the absolute change in luminance as a result of the onset of the new blue items. In all conditions, the fixation dot remained throughout the entire trial, and participants were asked to maintain their fixation on it until the final search display appeared.

Participants completed one block of trials for each condition, in a single session lasting less than $1 \mathrm{~h}$. The block order was counterbalanced, and trial sequence within a block was randomized individually for each participant. A single block consisted of 90 targetpresent trials, with equal numbers of left/right targets at each of the 


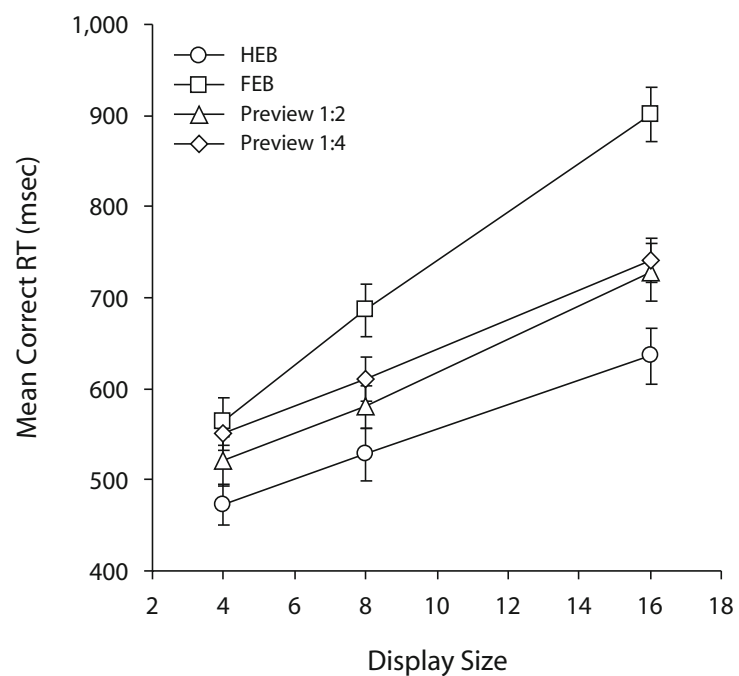

Figure 1. Mean correct response times (RTs) as a function of condition and display size for Experiment 1. In the preview conditions, the old items either doubled (Preview 1:2) or quadrupled (Preview 1:4) their luminance when the new items were added. Error bars indicate \pm 1 standard error.

three display sizes (30 trials per cell). In addition, there were 10 catch trials, in which no target was present. A 21-trial practice block was presented directly before each full block of trials.

\section{Results}

The mean correct RTs were determined for each condition $\times$ display size combination for each participant. The overall means are shown in Figure 1, and the associated search slopes and percentage error rates, in Tables 1 and 2. As in previous preview search studies, the data were analyzed by comparing the preview conditions with the HEB and FEB conditions. The HEB consisted of only the new items from the preview conditions, and the FEB consisted of all the items in the final display of the preview condition presented at once. Hence, by comparing search efficiency in the preview conditions and in the HEB and FEB, we can determine the degree to which observers were able to exclude the old previewed items from their search. Search efficiency in a preview condition should match that in the HEB if all old items can be excluded, whereas it should match that in the FEB if no old items can be excluded.

Table 1

Search Slopes (Milliseconds/Item) for Experiments 1 to 5

\begin{tabular}{lccccccc}
\hline \multicolumn{5}{c}{ HEB } & FEB & \multicolumn{5}{c}{ Preview Conditions } \\
\hline & & & PRE $_{1: 2}$ & PRE $_{1: 4}$ & & & \\
\cline { 4 - 7 } Exp. 1 & 13.6 & 28.0 & 17.4 & 15.8 & & & \\
& & & PRE $_{1: 1}$ & PRE $_{1: 4}$ & PRE $_{1: 6}$ & PRE $_{1: 8}$ & PRE $_{1: 10}$ \\
\cline { 4 - 7 } Exp. 2 & & 33.8 & 18.4 & 25.1 & 21.0 & 23.7 & 26.3 \\
& & & PRE & & & & \\
Exp.3 & 14.2 & 28.6 & 27.4 & & & & \\
Exp.4 & 31.9 & 47.7 & 42.6 & & & & \\
Exp.5 & 16.3 & 26.7 & 18.9 & & & & \\
\hline
\end{tabular}

\section{RTs}

HEB versus preview conditions. Mean correct RTs were analyzed using a 3 (condition: $\left.\mathrm{HEB}, \mathrm{PRE}_{1: 2}, \mathrm{PRE}_{1: 4}\right) \times$ 3 (display size: $4,8,16$ ) within-subjects ANOVA. As shown in Figure 1, RTs were shorter overall in the HEB condition $\left[F(2,18)=8.61, M S_{\mathrm{e}}=7,230.49, p<.005\right]$ and increased with display size $\left[F(2,18)=214.83, M S_{\mathrm{e}}=1,271.92, p<\right.$ $.001]$. However, the condition $\times$ display size interaction did not approach significance $\left[F(4,36)=1.23, M S_{\mathrm{e}}=\right.$ $1,187.67, p=.316]$, indicating that search efficiency did not differ between the three conditions.

FEB versus preview conditions. A similar withinsubjects ANOVA was performed for the FEB versus preview comparison. Both main effects and the interaction proved significant. RTs were longer overall in the FEB than in the preview conditions $[F(2,18)=12.35$, $\left.M S_{\mathrm{e}}=7,719.97, p<.001\right]$ and increased with display size $\left[F(2,18)=225.94, M S_{\mathrm{e}}=2,063.65, p<.001\right]$. However, of most interest, the RT increase over display sizes was greater for the FEB than for the preview conditions $\left[F(4,36)=14.35, M S_{\mathrm{e}}=1,150.48, p<.001\right]$, indicating that search was more efficient in the preview conditions than in the FEB.

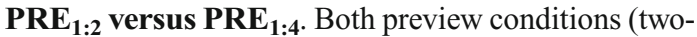
and fourfold luminance increments) were compared directly to assess the possibility that any difference between them had been obscured in the overall ANOVAs. RTs increased with display size $\left[F(2,18)=132.37 ; M S_{\mathrm{e}}=\right.$ $1,561.93, p<.001]$; however, neither the main effect of condition $\left[F(1,9)=1.29, M S_{\mathrm{e}}=7,148.37, p=.285\right]$ nor the condition $\times$ display size interaction $(F<1)$ approached significance.

\section{Errors}

As shown in Table 2 , errors were rare $(<0.5 \%$ overall $)$, and a 4 (condition: HEB, FEB, PRE $_{1: 2}, \mathrm{PRE}_{1: 4}$ ) $\times 3$ (display size: $4,8,16)$ within-subjects ANOVA revealed no significant main effects or interaction (all $F_{\mathrm{S}}<1$ ).

\section{Catch Trials}

The false alarm rate (i.e., responses indicating target presence on a catch trial) was relatively low overall $(<5 \%)$, and there were no significant main effects of condition or display size or significant interaction (all $p \mathrm{~s}>.15$ ).

\section{Discussion}

The main purpose of this experiment was to determine the effect on preview search of large (two- and fourfold) increases in luminance in old previewed items occurring when new items are added. As expected from previous findings (Watson \& Humphreys, 2002), a twofold increase in luminance when the new items were added had no reliable effect: Preview search was more efficient than the FEB, and it was no less efficient than in the HEB. These data are to be expected, on the basis of Rauschenberger's (2003) finding that changes in object status (from old to new) are only signaled by luminance changes greater than about threefold. Importantly, however, we found very similar results when old items underwent a fourfold increase in luminance. Again, preview search efficiency matched 
Table 2

Mean Percentage Error Rates As a Function of Experiment, Condition, and Display Size

\begin{tabular}{lccc}
\hline & \multicolumn{3}{c}{ Display Size } \\
\cline { 2 - 4 } Condition & 4 & 8 & 16 \\
\hline Experiment 1 & & & \\
HEB & 0.67 & 0.00 & 0.00 \\
FEB & 0.33 & 0.67 & 0.33 \\
Preview $_{1: 2}$ & 0.67 & 0.67 & 0.33 \\
Preview $_{1: 4}$ & 0.00 & 0.33 & 0.67 \\
Experiment $2^{\text {FEB }}$ & & & \\
Preview $_{1: 1}$ & 0.00 & 1.15 & 0.38 \\
Preview $_{1: 4}$ & 0.00 & 1.54 & 0.00 \\
Preview & 0.00 & 0.38 & 0.38 \\
Preview & 0.38 & 0.00 & 0.38 \\
Preview & 0.38 & 0.38 & 0.38 \\
Experiment 3 & 1.15 & 0.38 & 1.15 \\
HEB & & & \\
FEB & 0.28 & 0.00 & 0.83 \\
Preview & 0.83 & 0.00 & 0.56 \\
Experiment 4 & 0.56 & 0.83 & 2.50 \\
HEB & & & \\
FEB & 0.74 & 0.93 & 1.11 \\
Preview & 0.00 & 0.56 & 2.78 \\
Experiment 5 & 0.56 & 1.48 & 2.04 \\
HEB & & & \\
FEB & 0.00 & 0.56 & 0.28 \\
Preview & 0.83 & 1.11 & 0.28 \\
& 0.00 & 0.28 & 0.28 \\
\hline & & &
\end{tabular}

the HEB, whereas efficiency in these conditions increased relative to the FEB. The data indicate that the preview benefit is strikingly robust to changes in luminance in the old items, even when participants had previously been shown to treat such changes as representing the appearance of a new object (Rauschenberger, 2003). Experiment 2 examined this result further by assessing the effects of up to tenfold changes in the luminance of old items.

\section{EXPERIMENT 2}

\section{Four- to Tenfold Luminance Increments}

In Experiment 2, we explored a greater range of luminance changes to the old previewed items. We presented an FEB, along with five preview conditions in which the old items underwent $1: 1,1: 4,1: 6,1: 8$, or 1:10 increases in luminance when the new items were added. In the 1:1 condition, there was no change in luminance, so this represented a standard no-change preview condition, which has been used in previous studies (Watson \& Humphreys, 1997).

\section{Method}

\section{Participants}

A total of 13 participants (11 female, 2 male), 18-37 years of age $(M=21.2)$, took part in this experiment. All were undergraduate students at the University of Warwick with normal or corrected-tonormal visual acuity.

\section{Stimuli and Apparatus}

The stimuli and apparatus were essentially the same as in Experiment 1 , except that we presented five preview conditions in which the luminance increase ranged from zero to tenfold when the new blue items were added. In addition, to maintain a reasonable number of trials, we included only the FEB. In the no-change preview condition $\left(\mathrm{PRE}_{1: 1}\right)$, the previewed distractors did not change luminance when the new blue items were added. This was directly equivalent to the standard no-change preview conditions that had been presented in previous work (e.g., Watson \& Humphreys, 1997) and provided a baseline representing efficient preview search. In the remaining four preview conditions, an increase in luminance of approximately $1: 4$, $1: 6,1: 8$, and $1: 10$ occurred in the old previewed items when the new blue items were presented. Thus, the initial stimulus characteristics of the old preview green items in these conditions were $\mathrm{PRE}_{1: 4}$ $\mathrm{RGB}=7,112,73$; CIE $x y=0.263,0.488$; luminance $=9.3 \mathrm{~cd} / \mathrm{m}^{2}$; $\mathrm{PRE}_{1: 6}-\mathrm{RGB}=6,99,65$; CIE $x y=0.269,0.493$; luminance $=$ $6.1 \mathrm{~cd} / \mathrm{m}^{2} ; \mathrm{PRE}_{1: 8}-\mathrm{RGB}=5,91,59 ; \mathrm{CIE} x y=0.279,0.501 ; \mathrm{lu}-$ minance $=4.8 \mathrm{~cd} / \mathrm{m}^{2} ; \mathrm{PRE}_{1: 10}-\mathrm{RGB}=5,82,53 ; \mathrm{CIE} x y=0.285$, 0.498 ; luminance $=3.7 \mathrm{~cd} / \mathrm{m}^{2}$.

\section{Design and Procedure}

Each participant completed three blocks of trials. The first block was the FEB, followed by a block of preview trials, followed by a repeat of the FEB (an ABA design). The FEB was essentially the same as in Experiment 1, except that it contained 33 trials in a block (30 search trials, divided equally between each combination of left/right targets and display size, plus 3 no-target catch trials). The preview block consisted of 330 trials, of which 300 were search trials. The search trials were divided equally between left/right targets; display sizes of 4,8 , and 16 items; and the five different levels of luminance change. The remaining 30 trials were catch trials, on which no target was presented. The program automatically prompted participants to take a break after every 50 trials. This procedure resulted in 20 trials per cell in all of the conditions.

\section{Results}

\section{RTs}

The mean correct RTs are shown in Figure 2, with search slope statistics and mean percentage error rates in Tables 1 and 2 .

FEB versus preview conditions. The data were first analyzed by comparing RTs in all conditions using

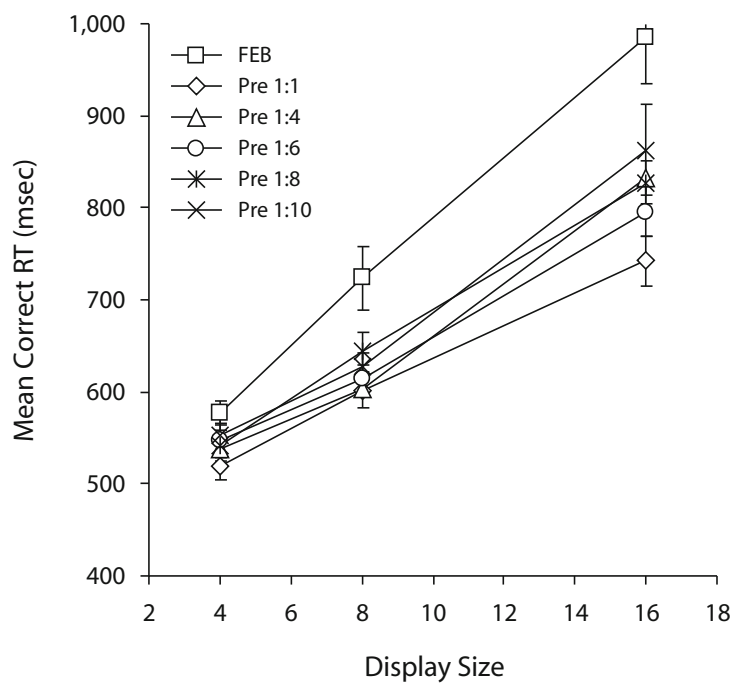

Figure 2. Mean correct response times (RTs) as a function of condition, display size, and luminance ratio increment for Experiment 2. Error bars indicate \pm 1 standard error. 
a 6 (condition: FEB, $\mathrm{PRE}_{1: 1}, \mathrm{PRE}_{1: 4}, \mathrm{PRE}_{1: 6}, \mathrm{PRE}_{1: 8}$, $\left.\mathrm{PRE}_{1: 10}\right) \times 3$ (display size: $4,8,16$ ) within-subjects ANOVA. This revealed significant main effects of condition $\left[F(5,60)=19.49, M S_{\mathrm{e}}=4,522.50, p<.001\right]$ and display size $\left[F(2,24)=194.44, M S_{\mathrm{e}}=9,150.49, p<.001\right]$, as well as a significant condition $\times$ display size interaction $\left[F(10,120)=3.90, M S_{\mathrm{e}}=3,877.58, p<.001\right]$. As shown in Figure 2, RTs were longest overall in the FEB, and the slope of the search function was also greatest in that condition. When we compared the preview with the largest luminance change $\left(\mathrm{PRE}_{1: 10}\right)$ with the $\mathrm{FEB}$, a significant main effect of condition $\left[F(1,12)=15.28, M S_{\mathrm{e}}=8,291.92, p<\right.$ $.01]$ and a significant condition $\times$ display size interaction $\left[F(2,24)=4.23, M S_{\mathrm{e}}=4,002.11, p<.05\right]$ emerged.

Preview conditions. Possible differences between the individual preview conditions were assessed with an additional ANOVA that excluded the FEB. This revealed significant main effects of condition $\left[F(4,48)=7.33, M S_{\mathrm{e}}=\right.$ $2,780.64, p<.001]$ and display size $[F(2,24)=200.52$, $\left.M S_{\mathrm{e}}=6,356.92, p<.001\right]$. As shown in Figure 2, overall RTs increased as the luminance of the preview items decreased, and also as display size increased. However, the condition $\times$ display size interaction did not approach significance $\left[F(8,96)=1.61, M S_{\mathrm{e}}=3,999.61, p=.131\right]$ : Thus, search efficiency did not differ between the preview conditions.

\section{Errors}

As shown in Table 2, errors were rare ( $<0.5 \%$ overall), and a 6 (condition: FEB, $\mathrm{PRE}_{1: 1}, \mathrm{PRE}_{1: 4}, \mathrm{PRE}_{1: 6}, \mathrm{PRE}_{1: 8}$, $\left.\mathrm{PRE}_{1: 10}\right) \times 3$ (display size: $\left.4,8,16\right)$ within-subjects ANOVA revealed no significant main effects or interaction (all $F \mathrm{~s}<1.5, p \mathrm{~s}>.225$ ).

\section{Catch Trials}

The false alarm rate was relatively low overall $(<2.5 \%)$, and there were no significant main effects of condition or display size, and no significant interaction (all $p \mathrm{~s}>.05$ ).

\section{Discussion}

The data reveal that search was more efficient in the preview conditions than in the FEB, and this result held even with a tenfold increase in luminance in the preview when the new items appeared, and when the absolute change in the preview items was greater than the luminance change that occurred with the onset of the new items. According to one view, based on prior results (Rauschenberger, 2003), the magnitude of the luminance change in the previewed items should have been sufficient to cause those items to be treated as new objects. Thus, all objects with "new object" status (in our experiments, the true new objects and those other objects defined by a luminance increase greater than 1:4) should have competed for attention, and the preview benefit should have been abolished, or at the very least reduced. Clearly this did not occur, perhaps because inhibitory processes suppressed the potency of the luminance changes in the old items.

Nonetheless, it is perhaps worth noting that in Experiments 1 and 2 the ratio of the luminance change at the new locations was greater than at the old locations, even when the absolute luminance change in the old locations was greater. It is thus possible that a hierarchy in attentional capture could exist, even within a class of new objects. This and other issues are addressed in the remaining experiments.

A second finding from Experiment 2 was a small increase in overall RTs as the luminance of the old items decreased. It has previously been observed that, although search efficiency in a preview condition can match that in the associated HEB, sometimes preview RTs are overall longer (producing an intercept but not a slope effect in search). A number of possibilities might explain why this would arise. However, one possibility supported by the data from Watson and Humphreys (1997) was that the task of inhibiting old items required the commitment of limited-capacity resources. One consequence of this could be a delayed onset of search through the new items, since attention then has to be switched from ignoring the old items to selecting the new (see also Mason, Humphreys, \& Kent, 2004; Watson \& Inglis, 2007). According to this proposal, the present data may be accounted for if more resources are required to inhibit less visible stimuli (such as those in the high-luminance-change conditions, when the preview was dimmer).

\section{EXPERIMENT 3 Reducing Color and Shape Differences Between Previewed and New Stimuli}

Experiments 1 and 2 established that the preview effect is remarkably resilient to large changes in the luminance of old items when new items appear. In the following experiments, we sought to establish the boundary conditions of this effect. For example, both Experiments 1 and 2 employed a version of preview search in which the old and new stimuli always differed in terms of a salient feature (their color). There is evidence of specific color-based suppression being involved in preview search utilizing both color-based grouping and segmentation of the stimuli and suppression of the color of the old group (see Braithwaite \& Humphreys, 2007; Braithwaite, Humphreys, \& Hulleman, 2005; Braithwaite et al., 2007). It may be that, when the old and new items are distinguished by color, even large luminance changes applied to the old items are ineffective in making these items compete for selection with the new stimuli. This was tested in Experiment 3, in which we used displays in which the old and new items had the same color (gray). Would the effects of luminance changes applied to the old items now be effective in disrupting search? In addition, we also equated the changes in luminance ratio as a result of the old items changing and the new items being presented (see our earlier discussion).

Here, both old and new items were associated with a ratio change of approximately $1: 4$; note, however, that this also meant that the absolute change in luminance was now much greater at the locations of the old preview items than of the new stimuli. Thus, these conditions were designed to increase the difficulty of preview search processes to the maximum. 


\section{Method}

\section{Participants}

A total of 12 participants ( 9 female, 3 male), 18-20 years of age $(M=18.7)$, took part in this experiment. All were undergraduate students at the University of Warwick with normal or corrected-tonormal visual acuity.

\section{Stimuli and Apparatus}

The stimuli consisted of the letters "Z," "H," "I," "N," and "X" presented in gray at three possible luminance levels, equivalent to approximately 15,20 , or $60 \mathrm{~cd} / \mathrm{m}^{2}$, against a gray background of approximately $5 \mathrm{~cd} / \mathrm{m}^{2}$. The exact stimulus values were as follows: background-RGB $=81,81,81$; CIE $x y=0.314,0.342$; luminance $=5.2 \mathrm{~cd} / \mathrm{m}^{2} ;$ dim gray-RGB $=118,118,118 ;$ CIE $x y=$ $0.300,0.328 ;$ luminance $=14.7 \mathrm{~cd} / \mathrm{m}^{2} ;$ medium gray-RGB $=131$, 131,131 ; CIE $x y=0.298,0.325$; luminance $=19.3 \mathrm{~cd} / \mathrm{m}^{2}$; light gray- $\mathrm{RGB}=199,199,199 ; \mathrm{CIE} x y=0.293,0.315 ;$ luminance $=$ $58.6 \mathrm{~cd} / \mathrm{m}^{2}$. The target letter was always a gray " $\mathrm{Z}$," displayed at a luminance of $20 \mathrm{~cd} / \mathrm{m}^{2}$, presented on the left or right side of the display among varying numbers of "H," "I," "N," and "X" distractor letters. The FEB consisted of search for a $20-\mathrm{cd} / \mathrm{m}^{2}$ "Z" among distractors with luminance values of either 20 or $60 \mathrm{~cd} / \mathrm{m}^{2}$. Displays were generated so that equal numbers of $20-$ and $60-\mathrm{cd} / \mathrm{m}^{2}$ items always appeared within a single display, with equal numbers of each on either side of the screen. As in Experiments 1 and 2, the display sizes in the FEB were 4, 8, and 16 items. In the preview condition, about half $(2,4$, or 8$)$ of the distractors were first presented alone, at a luminance level of $15 \mathrm{~cd} / \mathrm{m}^{2}$. After $1,000 \mathrm{msec}$, they increased in luminance to $60 \mathrm{~cd} / \mathrm{m}^{2}$ (representing a 1:4 increase in luminance and a $45-\mathrm{cd} / \mathrm{m}^{2}$ absolute change), and at the same time the remaining distractors and the " $Z$ " target were added to the display, all at a luminance of $20 \mathrm{~cd} / \mathrm{m}^{2}$ (a $1: 4$ increase in luminance and a $15-\mathrm{cd} / \mathrm{m}^{2}$ absolute change) - see Figure 3. The HEB was similar to the FEB, except that only half of the items were presented, all of which were at a luminance level of $20 \mathrm{~cd} / \mathrm{m}^{2}$ (i.e., equivalent to the presentation of just the new items from the preview condition).

\section{Design and Procedure}

Each participant completed one block of trials for each of the conditions, with block order completely counterbalanced across participants. As in Experiment 1, a single block contained 99 trials, with 90 search trials divided equally into each display size $\times$ target

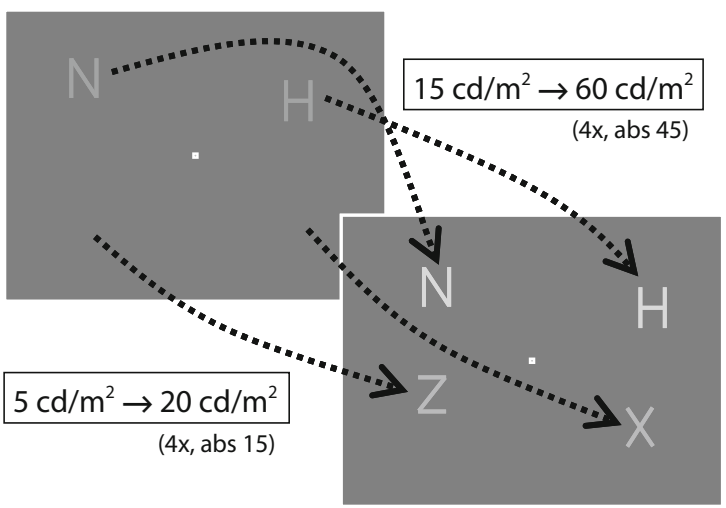

Figure 3. A sample trial sequence in the preview condition of Experiment 3. Preview distractors were first presented at a luminance of $15 \mathrm{~cd} / \mathrm{m}^{2}$. After $1,000 \mathrm{msec}$, these distractors increased to $60 \mathrm{~cd} / \mathrm{m}^{2}$ (an increase in absolute luminance of $45 \mathrm{~cd} / \mathrm{m}^{2}$, representing a change of $1: 4$ in ratio), and at the same time, the new distractors and target were presented at $20 \mathrm{~cd} / \mathrm{m}^{2}\left(\right.$ a $15-\mathrm{cd} / \mathrm{m}^{2}$ increment, also representing a 1:4 change).

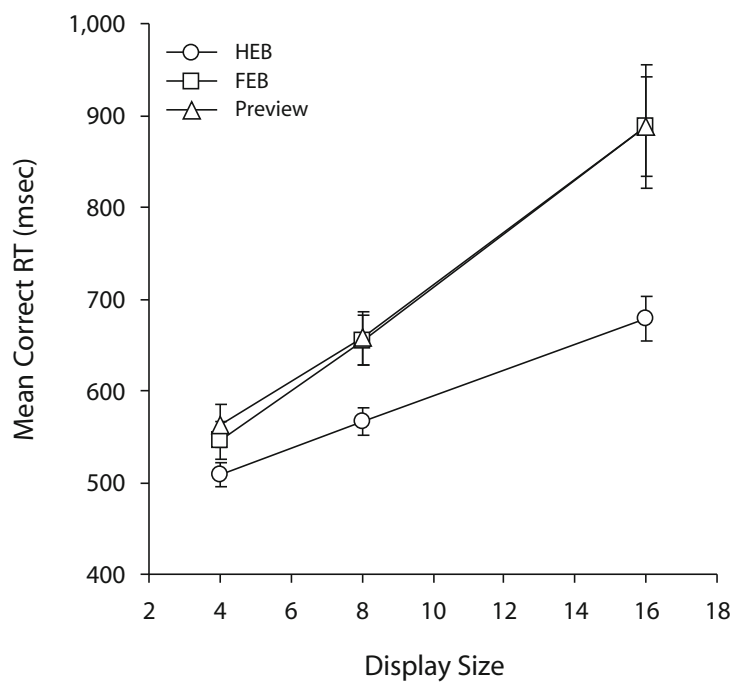

Figure 4. Mean correct response times (RTs) as a function of condition and display size for Experiment 3. Error bars indicate \pm 1 standard error

side combination, and 9 catch trials on which no target was present. Participants completed a practice block of 21 trials immediately before each full block.

\section{Results}

The mean correct RTs are shown in Figure 4, and the search slope values and percentage error rates are shown in Tables 1 and 2. As Figure 4 reveals, search in the preview condition was less efficient than in the HEB and matched that in the FEB.

\section{RTs}

HEB versus preview condition. Mean correct RTs were analyzed using a 2 (condition: HEB, preview) $\times 3$ (display size: $4,8,16$ ) within-subjects ANOVA. As shown in Figure 4, RTs were shorter overall in the $\operatorname{HEB}[F(1,11)=$ 12.47, $\left.M S_{\mathrm{e}}=20,253.49, p=.005\right]$ and increased with display size $\left[F(2,22)=47.78, M S_{\mathrm{e}}=8,110.16, p<.001\right]$. However, of most interest was a significant condition $\times$ display size interaction $\left[F(2,22)=12.57, M S_{\mathrm{e}}=3,122.24\right.$, $p<.001$ ], indicating that search was less efficient in the preview condition than in the HEB.

FEB versus preview condition. As expected, RTs increased as the display size increased $[F(2,22)=60.82$, $\left.M S_{\mathrm{e}}=11,566.93, p<.001\right]$. However, neither the main effect of condition nor the condition $\times$ display size interaction approached significance (both $F \mathbf{s}<1$ ). Thus, search in the preview condition was no more efficient than in the FEB on any measure of RT performance.

\section{Errors}

The average error rate was very low $(<1.0 \%)$, and a 3 (condition: FEB, HEB, preview) $\times 3$ (display size: 4,8 , 16) within-subjects ANOVA revealed no significant main effects or interaction (all $F_{\mathrm{s}}<2.2, p \mathrm{~s}>.138$ ). 


\section{Catch Trials}

The false alarm rate was very low overall $(<0.5 \%)$, and there were no significant main effects of condition or display size and no significant interaction (all $p \mathrm{~s}>.384$ ).

\section{Discussion}

In this experiment, we observed, for the first time here, an impact of luminance changes to the old elements on preview search efficiency-indeed, the preview benefit was totally abolished. ${ }^{3}$ Accordingly, search efficiency in the preview condition now matched that in the FEB and was reliably worse than that in the HEB. A critical factor might be that, when old and new items have the same color and are relatively heterogeneous in shape, participants are unable to use feature-based grouping and suppression of the old stimuli. Under these conditions, performance may depend, at least in part, on inhibition of the locations of the old items (see Watson \& Humphreys, 1997), on onset capture (Donk \& Theeuwes, 2001), or on temporal segmentation (Jiang et al., 2002b). Each of these processes may be disrupted by luminance changes to the old stimuli (see Watson et al., 2003, for discussion of why luminance change may disrupt location-based inhibition). In any case, a 1:4 luminance change in the old items appears to have been sufficient to cause them to recompete with the new elements.

Perhaps, by equating the ratios of luminance changes to the old and new items, we increased the effects of the change per se. Note that, to produce equal changes on the basis of a 1:4 ratio, the absolute increase in luminance of the old stimuli was much larger than the one created by onset of the new items ( $\left.45 \mathrm{vs} .15 \mathrm{~cd} / \mathrm{m}^{2}\right)$. This large absolute change in the luminance of the old stimuli could have been critical.

Experiments 4 and 5 tested whether color differences between the old and new items, and the absolute levels of the changes in their luminance, were important to performance. Experiment 4 assessed whether grouping using shape rather than color similarity would protect preview search against luminance increments added to old stimuli. In this study, the old and new items again had the same color (as in Experiment 3), but now each set of items (i.e., the old and new item sets and the target) was grouped separately by shape. The preview condition consisted of upright "T"s for $1 \mathrm{sec}$, followed by "T"s rotated $90^{\circ}$ clockwise and an inverted " $T$ " target. If participants can use common shape features to help group and suppress old stimuli, search in these conditions should be enhanced relative to when more heterogeneous stimuli were used (i.e., in Experiment 3; see Kunar \& Humphreys, 2006, for evidence of shape-based inhibition with these types of displays). More particularly, the disruptive effects of the luminance change applied to old items might be eliminated. Note that, if this is the case, the critical factor cannot be color differences, but rather the grouping and segmentation of the old and new displays.

In Experiment 5, we used the same luminance increments as in Experiment 3, but introduced a color difference between the old and the new displays.

\section{EXPERIMENT 4 \\ The Effects of Shape Grouping and Segmentation}

\section{Method}

\section{Participants}

A total of 18 participants (15 female, 3 male), 18-31 years of age $(M=20.2)$, took part in this experiment. All were undergraduate students at the University of Warwick with normal or corrected-tonormal visual acuity.

\section{Stimuli and Apparatus}

The experimental conditions were similar overall to those in Experiment 3, except that "T" rather than "Z," "H," "I," "N," and "X" stimuli were used. The target was an inverted "T" $(7 \times 7 \mathrm{~mm})$, and the distractors were upright " $T$ "s and " $T$ "s rotated $90^{\circ}$ clockwise (see Olivers et al., 1999, for an earlier use of similar stimuli in preview search). On FEB search trials, the display consisted of an inverted $20-\mathrm{cd} / \mathrm{m}^{2}$ target " $\mathrm{T}$ " among $20-\mathrm{cd} / \mathrm{m}^{2}$ distractor "T"s rotated $90^{\circ}$ clockwise and $60-\mathrm{cd} / \mathrm{m}^{2}$ upright distractor "T"s. As in the previous experiments, the task was to indicate on which side of the display the target appeared. In the preview condition, about half of the distractors (i.e., 2, 4, or 8 upright "T" distractors) were first presented alone at a luminance level of $15 \mathrm{~cd} / \mathrm{m}^{2}$. After $1,000 \mathrm{msec}$, they increased in luminance to $60 \mathrm{~cd} / \mathrm{m}^{2}$ (representing a 1:4 increase in luminance and a $45-\mathrm{cd} / \mathrm{m}^{2}$ absolute change), and at the same time the remaining distractors ("T"s rotated $90^{\circ}$ clockwise) and the inverted " $\mathrm{T}$ " target were added to the display at a luminance of $20 \mathrm{~cd} / \mathrm{m}^{2}$ (a 1:4 increase in luminance and a $15-\mathrm{cd} / \mathrm{m}^{2}$ absolute change), to make a total display size of 4,8 , or 16 items. The HEB consisted of just the new items from the preview condition (the inverted " $\mathrm{T}$ " target and the "T"s rotated $90^{\circ}$ clockwise) at a luminance level of $20 \mathrm{~cd} / \mathrm{m}^{2}$.

\section{Design and Procedure}

The design and procedure were the same as in Experiment 3.

\section{Results}

The mean correct RTs are shown in Figure 5, and the search slope values and percentage error rates are shown in Tables 1 and 2. As Figure 5 reveals, search in the pre-

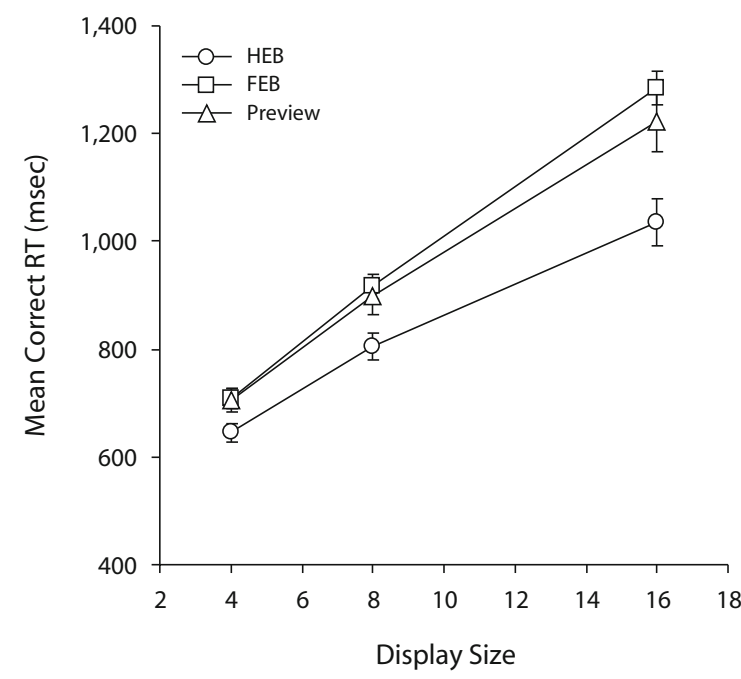

Figure 5. Mean correct response times (RTs) as a function of condition and display size for Experiment 4. Error bars indicate \pm 1 standard error. 
view condition was less efficient than in the HEB and only slightly more efficient than in the FEB.

\section{RTs}

HEB versus preview condition. The mean correct $R T s$ were analyzed using a 2 (condition: HEB, preview) $\times 3$ (display size: $4,8,16$ ) within-subjects ANOVA. As shown in Figure 5, RTs were overall shorter in the $\operatorname{HEB}[F(1,17)=$ 14.66, $\left.M S_{\mathrm{e}}=23,501.38, p=.001\right]$, and RTs increased with display size $\left[F(2,34)=170.96, M S_{\mathrm{e}}=10,958.49\right.$, $p<.001]$. However, of most interest was a significant condition $\times$ display size interaction $\left[F(2,34)=7.76, M S_{\mathrm{e}}=\right.$ $5,008.15, p=.002]$, indicating that search was less efficient in the preview condition than in the HEB.

FEB versus preview condition. RTs increased with display size $\left[F(2,34)=304.22, M S_{\mathrm{e}}=9,029.88, p<\right.$ $.001]$. However, although there was a numerical trend for search in the preview condition to be more efficient than in the FEB (42 vs. $48 \mathrm{msec} /$ item, respectively), neither the main effect of condition nor the condition $X$ display size interaction approached significance (both $F \mathrm{~s}<1.5$, both $p \mathrm{~s}>.3$ ).

\section{Errors}

The average error rate was very low $(<1.2 \%)$; however, a 3 (condition: FEB, HEB, preview) $\times 3$ (display size: 4 , $8,16)$ within-subjects ANOVA revealed that error rates increased with display size $\left[F(2,34)=6.29, M S_{\mathrm{e}}=5.25\right.$, $p<.01]$ and that this increase was greater for the preview condition and the FEB $\left[F(4,68)=2.99, M S_{\mathrm{e}}=2.78, p<\right.$ $.05]$. The main effect of condition did not approach significance $(F<1)$. Thus, the more efficient search attained in the HEB than in the preview condition did not come at the expense of making more errors.

\section{Catch Trials}

The false alarm rate was very low overall $(<2.1 \%)$, and no significant main effects of condition or display size or significant interaction emerged (all $p \mathrm{~s}>.07$ ).

\section{Discussion}

In this experiment, the opportunity for shape-based grouping within the old and the new sets, and for shapebased segmentation between the sets, was increased relative to Experiment 3. Previous studies have demonstrated effective grouping for " $\mathrm{T}$ " stimuli of the type used here (Humphreys \& Müller, 1993; Humphreys, Quinlan, \& Riddoch, 1989). Nonetheless, we again found that the luminance increment introduced among the old items reduced the preview benefit - in this case, to a nonreliable $6 \mathrm{msec} /$ item on the search slope for the preview relative to the FEB. ${ }^{4}$ This suggests that, in the absence of color differences between the displays, preview search remains vulnerable to disruption from large luminance increments in the old stimuli. However, as we have noted, the magnitude of the luminance change could also be critical. Experiment 5 evaluated whether the preview benefit could survive the luminance increments used in Experiments 4 and 5 when the old and new displays were segmented by color.

\section{EXPERIMENT 5 \\ The Effect of Color Grouping and Segmentation}

The luminance manipulations in Experiment 5 were essentially the same as those in Experiments 3 and 4, except that here we introduced a color difference between the old and the new items. Specifically, as in Experiments 1 and 2 , we used as our stimuli green " $\mathrm{H}$ "s (for the preview displays) and blue "A"s and a blue " $H$ " target (for the search displays).

\section{Method \\ Participants \\ A total of 12 participants (11 female, 1 male), 18-36 years of age $(M=20.5)$, took part in this experiment. All were undergraduate students at the University of Warwick with normal or corrected-to- normal visual acuity.}

\section{Stimuli and Apparatus}

The experimental conditions were similar overall to those in Experiment 4, except that the target was a blue letter " $\mathrm{H}$ " and the distractors were green "H"s and blue "A"s. On FEB search trials, a display consisted of a $20-\mathrm{cd} / \mathrm{m}^{2}$ blue " $\mathrm{H}$ " target among $60-\mathrm{cd} / \mathrm{m}^{2}$ green " $\mathrm{H}$ " and $20-\mathrm{cd} / \mathrm{m}^{2}$ blue "A" distractors. As in the previous experiments, the task was to indicate the side of the display on which the target appeared. The exact stimulus values were as follows: background- $\mathrm{RGB}=81$, 81,$81 ;$ CIE $x y=0.314,0.342$; luminance $=5.2 \mathrm{~cd} / \mathrm{m}^{2} ;$ dim green$\mathrm{RGB}=8,135,88$; CIE $x y=0.254,0.470$; luminance $=14.7 \mathrm{~cd} / \mathrm{m}^{2}$; bright green-RGB $=14,230,150$; CIE $x y=0.243$, 0.452; luminance $=59.3 \mathrm{~cd} / \mathrm{m}^{2}$; blue- RGB $=59,141,152 ;$ CIE $x y=0.212$, 0.285 ; luminance $=20.06 \mathrm{~cd} / \mathrm{m}^{2}$. In the preview condition, half of the distractors $(2,4$, or 8 green " $H$ "s) were first presented alone at a luminance level of $15 \mathrm{~cd} / \mathrm{m}^{2}$. After $1,000 \mathrm{msec}$, they increased in luminance to $60 \mathrm{~cd} / \mathrm{m}^{2}$ (representing a 1:4 increase in luminance and a $45-\mathrm{cd} / \mathrm{m}^{2}$ absolute change), and at the same time the remaining distractors (blue "A"s) and the blue " $\mathrm{H}$ " target were added to the display at a luminance level of $20 \mathrm{~cd} / \mathrm{m}^{2}$ (a 1:4 increase in luminance and a $15-\mathrm{cd} / \mathrm{m}^{2}$ absolute change), to make a total display size of 4,8 , or 16 items. The HEB consisted of just the new items from the preview condition (the blue " $\mathrm{H}$ " target and "A" distractors) at a luminance level of $20 \mathrm{~cd} / \mathrm{m}^{2}$.

\section{Design and Procedure}

The design and procedure were the same as in Experiment 4.

\section{Results}

Mean correct RTs are shown in Figure 6, and search slope values and percentage error rates are shown in Tables 1 and 2. As can be seen in Figure 6, on the basis of search slopes, search was more efficient in the preview condition than in the FEB and matched that in the HEB.

\section{RTs}

HEB versus preview condition. Mean correct RTs were analyzed using a 2 (condition: HEB, preview) $\times 3$ (display size: $4,8,16$ ) within-subjects ANOVA. As shown in Figure 6, RTs were shorter overall in the HEB $[F(1,11)=$ $\left.32.46, M S_{\mathrm{e}}=3,451.87, p<.001\right]$ and increased with display size $\left[F(2,22)=156.22, M S_{\mathrm{e}}=1,770.88, p<.001\right]$. However, critically, the condition $\times$ display size interaction did not approach significance $\left[F(2,22)=1.57, M S_{\mathrm{e}}=\right.$ $970.06, p=.231]$, indicating that search was no less efficient in the preview condition than in the HEB.

FEB versus preview condition. RTs were slower overall in the FEB than in the preview condition $[F(1,11)=$ 


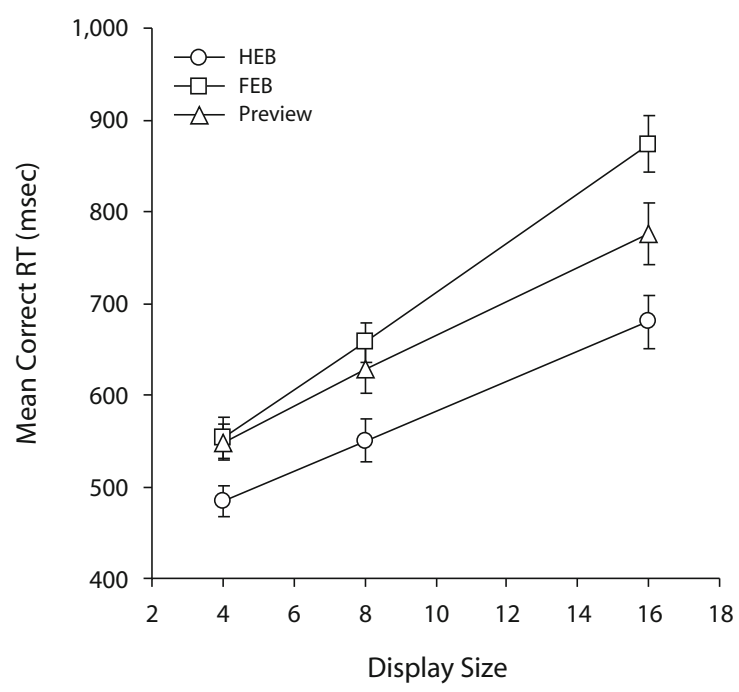

Figure 6. Mean correct response times (RTs) as a function of condition and display size for Experiment 5. Error bars indicate \pm 1 standard error.

7.34, $\left.M S_{\mathrm{e}}=4,828.88, p=.020\right]$ and increased with display size $\left[F(2,22)=251.22, M S_{\mathrm{e}}=1,851.55, p<.001\right]$. Of most interest, the condition $\times$ display size interaction was also significant $\left[F(2,22)=5.88, M S_{\mathrm{e}}=2,349.15\right.$, $p<.01]$, indicating that search was more efficient in the preview condition than in the FEB.

\section{Errors}

The average error rate was very low $(<0.5 \%)$, and none of the main effects or the interaction proved significant (all $F \mathrm{~s}<3.4$, all $p \mathrm{~s}>.05)$.

\section{Catch Trials}

The false alarm rate was very low overall $(<4.4 \%)$, and no significant main effects of condition or display size or significant interaction emerged (all $p \mathrm{~s}>.09$ ).

\section{Discussion}

In Experiments 3 and 4, there was no color difference between the old and new displays, in which conditions a substantial luminance increment to the old items disrupted the preview benefit in search. In contrast, the old and new stimuli in Experiment 5 did differ in color. In this case, when the same luminance increase was applied as in Experiments 3 and 4, the preview benefit remained. The slope of the search function in the preview condition matched that in the HEB, whereas the slope for preview search was reduced relative to the FEB. Thus, even though the absolute luminance change occurring in the preview items was again considerably greater than that associated with new items, and though the luminance ratio changes were equivalent for old and new items, the old items still failed to compete for selection with the new stimuli. This result provides strong evidence for a role of color grouping and segmentation in search over time, which minimizes the effects associated with onset capture (e.g., from luminance increments ap- plied to old items). The data are consistent with the idea that participants group old items by color and suppress both the group and the associated color representations (see Braithwaite, Humphreys, \& Hulleman, 2005, for evidence for separate effects of color grouping and color-based suppression in preview search). In addition, participants may also adopt a positive expectancy for the target's color (see, e.g., Braithwaite \& Humphreys, 2003; Braithwaite et al., 2003, 2004; Watson \& Humphreys, 2005), helping to mitigate any effects of luminance change in the old stimuli. The experiment also demonstrates that the substantial luminance increment to old stimuli (matched for the ratio of luminance change of new onsets) was not sufficient to eradicate the preview benefit in search. The magnitude of the luminance increment here seems to have been less critical than whether the old and new items differed in color.

\section{GENERAL DISCUSSION}

We examined the effects of luminance changes applied to old stimuli in preview search. Specifically, we examined whether luminance changes that have been proposed to signal the presentation of new perceptual objects (Rauschenberger, 2003) are sufficient to cause previewed items to recompete for selection with the new stimuli. In all of the present experiments, we applied luminance changes to old items concurrent with the onset of new search items. The relative changes in the luminance of the old items could be as much as 1:10 (Experiment 2), and at least as large as the relative change in luminance brought about by the occurrence of the new onsets (Experiment 5), yet these changes had no impact on the preview benefit in search, provided that the old and new stimuli differed in color. In contrast, luminance increments to old items did disrupt the preview benefit when the old and new items differed only in shape, even when shape-based grouping could facilitate segmentation of the displays (Experiment 4). These results have important implications for understanding the factors that contribute to preview search.

\section{Luminance Change and Preview Search}

As we discussed in the introduction, previous studies have demonstrated that preview search can be disrupted if old items undergo certain changes. In particular, the preview benefit is eliminated by changes likely to indicate an alteration in the state of the perceptual object being ignored (e.g., when old items change shape; see Watson \& Humphreys, 2002). Studies examining attentional capture from new onsets have also shown that luminance increments at a ratio of 1:4 or above can lead to the classification of a stimulus as a new object (Rauschenberger, 2003). Despite this last result, we found that similar ratio increases in the luminance of old items did not make them recompete for selection with new stimuli, provided that the old and new items were segmented by color (Experiments 1, 2, and 5).

These data contradict accounts of preview search in terms of the capture of attention by new onsets (Donk \& Theeuwes, 2001) and of temporal segmentation of old and new stimuli (Jiang et al., 2002b). Increases in the luminance of old items on the order of a 1:10 ratio should be sufficient to 
compete with the luminance increments associated with new stimuli (Rauschenberger, 2003). If the preview benefit were due solely to onset capture, it should have been eliminated under these circumstances. Clearly, it was not. Similarly, the onset cues leading to temporal segmentation between the preview and search displays should have been disrupted by the large luminance increments to the old items here. If temporal segmentation alone were critical (Jiang et al., 2002b), the preview effect should again have been reduced. In addition, neither the onset capture account nor the temporal segmentation account distinguishes between search when old and new items differ in color and search when they do not. Although our claim remains highly controversial, we have previously argued, from a number of perspectives, that the onset and temporal segmentation accounts cannot explain the full set of preview results now available (see, e.g., Braithwaite, Hulleman, Watson, \& Humphreys, 2006; Braithwaite, Humphreys, \& Hulleman, 2005; Braithwaite, Humphreys, Watson, \& Hulleman, 2005; Hodsoll \& Humphreys, 2005; Humphreys, Olivers, \& Yoon, 2006; Humphreys, Stalmann, \& Olivers, 2004; Humphreys, Watson, \& Jolicœur, 2002; Kunar et al., 2003a, 2003b; Kunar et al., 2006; Olivers \& Humphreys, 2003; Watson \& Humphreys, 1997, 2002, 2005; Watson et al., 2003; Watson \& Maylor, 2002). The present data add to this growing list.

The data also demonstrate that color differences between old and new items are important to preview search, and the presence of a color difference enables processes to come into play that make search robust to luminance changes in the old items. In line with previous research (Braithwaite \& Humphreys, 2003, 2007; Braithwaite et al., 2003, 2004; Braithwaite, Humphreys, \& Hulleman, 2005; Braithwaite et al., 2007), we suggest that color is important because it enables old items to be grouped and suppressed together, because the color of the old display can be inhibited and a positive expectancy for the target's color can be adopted. Effects of color grouping were shown by Braithwaite, Humphreys, and Hulleman (2005). In their study, probes were difficult to detect when presented on old items carrying the majority color in a preview, and this occurred even when the old items changed color when the new search stimuli appeared. Thus, apparently the color group was suppressed, not their color per se. Separate effects of color inhibition were also shown, because probes were also difficult to detect when they fell on new stimuli that carried the majority color of the old distractors (see also Braithwaite \& Humphreys, 2007). Similar data were reported by Olivers and Humphreys (2003), who found that a color singleton in a search display was much less effective in capturing attention when it was the same color as the previewed distractors. This occurred even when the old distractors were removed from a display at the onset of the new stimuli.

Effects of an expectancy for the target color were reported by Braithwaite and Humphreys (2003; see also Braithwaite et al., 2004): Targets were difficult to detect if they carried the color of the previewed items. However, this effect of color inhibition was significantly reduced (but not abolished) when participants expected the target's color. These processes, either alone or in combination, would be sufficient to prevent luminance changes from effectively making old items compete as new stimuli. Interestingly, in a recent study of preview search using psychophysical procedures, Allen and Humphreys (2007) found that sensitivity to luminance increments was reduced when the increments fell on old items that were likely to be followed by a new search display, relative to when they fell on the same stimuli in a condition in which a preview search task was not predicted. These data indicate an association between the active ignoring of old items and a reduction in their effective contrast. Allen and Humphreys studied search under conditions in which old and new items had the same color. Our results suggest that similar processes may take place, but perhaps even more strongly, when the old and new items also differ in color. The extra reduction in sensitivity to the contrast of the old items means that luminance increments for these stimuli will be less effective in capturing attention.

Nevertheless, large luminance increments for the old display items here did disrupt the preview benefit when the old and new items were the same color (Experiments 3 and 4). This may result from a reduction in the magnitude of contrast produced by the proposed suppression of the old items (see our discussion of Allen \& Humphreys, 2007, above). Such suppression effects may be greater when color can be inhibited along with the locations of the old items. Our results may also reflect the specific influence of expectancy for the target color, which could not come into play when the old and new items have the same color. In addition, luminance increments may be disruptive when the old and new items share color, because the anticipatory set specifies that the new targets will be defined by onsets. Watson and Humphreys (2005) put forward this proposal when discussing the effects of irrelevant changes added to preview displays. Future work needs to separate out which of the factors linked to the use of color in preview search are crucial for modulating the effects of luminance increments on old stimuli.

Note that we are not proposing that color necessarily plays a unique role in feature-based inhibitory processes within preview search. It remains perfectly reasonable to assume that a sufficiently salient shape difference between old and new items might also lead to efficient preview search under the luminance increase conditions we have explored. Perhaps the size of our color difference, but not of our shape difference, allowed feature-based suppression to be effective. The main point is that we have demonstrated that feature-based processes (here, based on color) can contribute to keeping old items from competing for selection over time. In more general terms, the suppressive mechanism we have characterized as visual marking (Watson et al., 2003) can be conceptualized as employing a variety of inhibitory processes applied in a flexible manner, depending on the features available, to prioritize search among new stimuli.

\section{Ecological Considerations}

At the start of this article, we considered the ecological properties of visual selection over time. When considering previous studies of the effects of irrelevant changes on preview search, we noted that attention should be drawn primarily to changes that are likely to be behaviorally relevant (such as variation in the shape of an old stimulus; 
see Watson \& Humphreys, 2005). We can accommodate the present results within this framework if we consider the different properties of the displays as signaling behavioral relevance in terms of weighted probabilities. To go beyond a redescription of the data, though, we will need to vary factors that can be independently defined as having behavioral relevance and to assess how these factors are modulated by different task sets. This issue awaits further research.

\section{AUTHOR NOTE}

This work was supported by grants from the BBSRC, the ESRC, and the MRC (U.K.). We thank Mieke Donk and Robert Rauschenberger for valuable comments and suggestions. Correspondence related to this article may be sent to D. G. Watson, Department of Psychology, University of Warwick, Coventry CV4 7AL, England (e-mail: d.g.watson@ warwick.ac.uk).

Note-Accepted by the editorial board of Editor-Elect Jeremy M. Wolfe.

\section{REFERENCES}

Agter, F., \& Donk, M. (2005). Prioritized selection in visual search through onset capture and color inhibition: Evidence from a probe-dot detection task. Journal of Experimental Psychology: Human Perception \& Performance, 31, 722-730.

Allen, H. A., \& Humphreys, G. W. (2007). Previewing distracters reduces their effective contrast. Vision Research, 47, 2992-3000.

Allen, H. A., Humphreys, G. W., \& Matthews, P. M. (2008). A neural marker of content-specific active ignoring. Journal of Experimental Psychology: Human Perception \& Performance, 34, 286-297.

Belopolsky, A. V., Peterson, M. S., \& Kramer, A. F. (2005). Visual search in temporally segregated displays: Converging operations in the study of the preview benefit. Cognitive Brain Research, 24, 453-466.

Braithwaite, J. J., Hulleman, J., Watson, D. G., \& Humphreys, G. W. (2006). Is it impossible to inhibit isoluminant items, or does it simply take longer? Evidence from preview search. Perception \& Psychophysics, 68, 290-300.

Braithwaite, J. J., \& Humphreys, G. W. (2003). Inhibition and anticipation in visual search: Evidence from effects of color foreknowledge on preview search. Perception \& Psychophysics, 65, 213-237.

Braithwaite, J. J., \& Humphreys, G. W. (2007). Filtering items of mass distraction: Top-down biases against distractors are necessary for the feature-based carry-over to occur. Vision Research, 47, 15701583.

Braithwaite, J. J., Humphreys, G. W., \& Hodsoll, J. (2003). Color grouping in space and time: Evidence from negative color-based carryover effects in preview search. Journal of Experimental Psychology: Human Perception \& Performance, 29, 758-778.

Braithwaite, J. J., Humphreys, G. W., \& Hodsoll, J. (2004). Effects of colour on preview search: Anticipatory and inhibitory biases for colour. Spatial Vision, 17, 389-415.

Braithwaite, J. J., Humphreys, G. W., \& Hulleman, J. (2005). Colorbased grouping and inhibition in visual search: Evidence from a probe detection analysis of preview search. Perception \& Psychophysics, 67, 81-101.

Braithwaite, J. J., Humphreys., G. W., Hulleman, J., \& Watson, D. G. (2007). Fast color grouping and slow color inhibition: Evidence for distinct temporal windows for separate processes in preview search. Journal of Experimental Psychology: Human Perception \& Performance, 33, 503-517.

Braithwaite, J. J., Humphreys, G. W., Watson, D. G., \& HulleMAN, J. (2005). Revisiting preview search at isoluminance: New onsets are not necessary for the preview advantage. Perception \& Psychophysics, 67, 1214-1228.

Chun, M. M., \& Wolfe, J. M. (1996). Just say no: How are visual searches terminated when there is no target present? Cognitive Psychology, 30, 39-78.

Davoli, C. C., Suszko, J. W., \& Abrams, R. A. (2007). New objects can capture attention without a unique luminance transient. Psychonomic Bulletin \& Review, 14, 338-343.

Donk, M. (2005). Prioritizing selection of new elements: On the time course of the preview effect. Visual Cognition, 12, 1373-1385.

Donk, M. (2006). The preview benefit: Visual marking, feature-based inhibition, temporal segregation, or onset capture? Visual Cognition, 14, 736-748.

DonK, M., \& Theeuwes, J. (2001). Visual marking beside the mark: Prioritizing selection by abrupt onsets. Perception \& Psychophysics, 63, 891-900.

Donk, M., \& Theeuwes, J. (2003). Prioritizing selection of new elements: Bottom-up versus top-down control. Perception \& Psychophysics, 65, 1231-1242.

Donk, M., \& Verburg, R. C. (2004). Prioritizing new elements with a brief preview period: Evidence against visual marking. Psychonomic Bulletin \& Review, 11, 282-288.

Downing, C. J., \& Pinker, S. (1985). The spatial structure of visual attention. In M. I. Posner \& O. S. M. Marin (Eds.), Attention and performance XI: Mechanisms of attention and visual search (pp. 171188). Hillsdale, NJ: Erlbaum.

ERIKSEN, C. W., \& ST. JAMES, J. D. (1986). Visual attention within and around the field of focal attention: A zoom lens model. Perception \& Psychophysics, 40, 225-240.

Folk, C. L., Remington, R. W., \& Johnston, J. C. (1992). Involuntary covert orienting is contingent on attentional control settings. Journal of Experimental Psychology: Human Perception \& Performance, 18, 1030-1044.

FolK, C. L., Remington, R. W., \& Wright, J. H. (1994). The structure of attentional control: Contingent attentional capture by apparent motion, abrupt onset, and color. Journal of Experimental Psychology: Human Perception \& Performance, 20, 317-329.

Franconeri, S. L., Hollingworth, A., \& Simons, D. J. (2005). Do new objects capture attention? Psychological Science, 16, 275-281.

Hodsoll, J. P., \& Humphreys, G. W. (2005). Preview search and contextual cuing. Journal of Experimental Psychology: Human Perception \& Performance, 31, 1346-1358.

Humphreys, G. W., Kyllingsbæk, S., Watson, D. G., Olivers, C. N. L., Law, I., \& Paulson, O. B. (2004). Parieto-occipital areas involved in efficient filtering in search: A time course analysis of visual marking using behavioural and functional imaging procedures. Quarterly Journal of Experimental Psychology, 57A, 610-635.

Humphreys, G. W., \& MülleR, H. J. (1993). SEarch via Recursive Rejection (SERR): A connectionist model of visual search. Cognitive Psychology, 25, 43-110.

Humphreys, G. W., Olivers, C. N. L., \& Braithwaite, J. J. (2006). The time course of preview search with color-defined, not luminancedefined, stimuli. Perception \& Psychophysics, 68, 1351-1358.

Humphreys, G. W., Olivers, C. N. L., \& Yoon, E. Y. (2006). An onset advantage without a preview benefit: Neuropsychological evidence separating onset and preview effects in search. Journal of Cognitive Neuroscience, 18, 110-120.

Humphreys, G. W., Quinlan, P. T., \& RidDoch, M. J. (1989). Grouping processes in visual search: Effects with single- and combinedfeature targets. Journal of Experimental Psychology: General, 118, 258-279.

Humphreys, G. W., Stalmann, B. J., \& Olivers, C. (2004). An analysis of the time course of attention in preview search. Perception \& Psychophysics, 66, 713-730.

Humphreys, G. W., Watson, D. G., \& Joliceur, P. (2002). Fractionating the preview benefit in search: Dual-task decomposition of visual marking by timing and modality. Journal of Experimental Psychology: Human Perception \& Performance, 28, 640-660.

JaCOBSEn, T., Humphreys, G. W., SChröger, E., \& Roeber, U. (2002). Visual marking for search: Behavioral and event-related potential analyses. Cognitive Brain Research, 14, 410-421.

JiAnG, Y., Chun, M. M., \& Marks, L. E. (2002a). Visual marking: Dissociating effects of new and old set size. Journal of Experimental Psychology: Learning, Memory, \& Cognition, 28, 293-302.

Jiang, Y., Chun, M. M., \& Marks, L. E. (2002b). Visual marking: Selective attention to asynchronous temporal groups. Journal of Experimental Psychology: Human Perception \& Performance, 28, 717-730. JIANG, Y., \& WANG, S. W. (2004). What kind of memory supports visual 
marking? Journal of Experimental Psychology: Human Perception \& Performance, 30, 79-91.

JiNGLING, L., \& YeH, S.-L. (2007). New objects do not capture attention without a top-down setting: Evidence from an inattentional blindness task. Visual Cognition, 15, 661-684.

Kahneman, D., Treisman, A., \& Burkell, J. (1983). The cost of visual filtering. Journal of Experimental Psychology: Human Perception \& Performance, 9, 510-522.

KaWAhara, J.-I., \& Yamada, Y. (2006). Two noncontiguous locations can be attended concurrently: Evidence from the attentional blink. Psychonomic Bulletin \& Review, 13, 594-599.

Kramer, A. F., \& Atchley, P. (2000). Age-related effects in the marking of old objects in visual search. Psychology \& Aging, 15, 286-296.

Kramer, A. F., \& HAhN, S. (1995). Splitting the beam: Distribution of attention over noncontiguous regions of the visual field. Psychological Science, 6, 381-386.

Kunar, M. A., \& Humphreys, G. W. (2006). Object-based inhibitory priming in preview search: Evidence from the "top-up" procedure. Memory \& Cognition, 34, 459-474.

Kunar, M. A., Humphreys, G. W., \& Smith, K. J. (2003a). History matters: The preview benefit in search is not onset capture. Psychological Science, 14, 181-185.

Kunar, M. A., Humphreys, G. W., \& Smith, K. J. (2003b). Visual change with moving displays: More evidence for color feature map inhibition during preview search. Journal of Experimental Psychology: Human Perception \& Performance, 29, 779-792.

Kunar, M. A., Humphreys, G. W., Smith, K. J., \& Watson, D. G. (2003). When a reappearance is old news: Visual marking survives occlusion. Journal of Experimental Psychology: Human Perception \& Performance, 29, 185-198.

Kunar, M. A., Shapiro, K. L., \& Humphreys, G. W. (2006). Top-up search and the attentional blink: A two-stage account of the preview effect in search. Visual Cognition, 13, 677-699.

Mason, D. J., Humphreys, G. W., \& Kent, L. (2004). Visual search, singleton capture, and the control of attentional set in ADHD. Cognitive Neuropsychology, 21, 661-687.

Olivers, C. N. L., \& Humphreys, G. W. (2002). When visual marking meets the attentional blink: More evidence for top-down, limitedcapacity inhibition. Journal of Experimental Psychology: Human Perception \& Performance, 28, 22-42.

Olivers, C. N. L., \& Humphreys, G. W. (2003). Visual marking inhibits singleton capture. Cognitive Psychology, 47, 1-42.

Olivers, C. N. L., Humphreys, G. W., \& Braithwaite, J. J. (2006) The preview search task: Evidence for visual marking. Visual Cognition, 14, 716-735.

Olivers, C. N. L., Humphreys, G. W., Heinke, D., \& Cooper, A. C. G. (2002). Prioritization in visual search: Visual marking is not dependent on a mnemonic search. Perception \& Psychophysics, 64, 540-560.

Olivers, C. N. L., Smith, S., Matthews, P., \& Humphreys, G. W. (2005). Prioritizing new over old: An fMRI study of the preview search task. Human Brain Mapping, 24, 69-78.

Olivers, C. N. L., Watson, D. G., \& Humphreys, G. W. (1999). Visual marking of locations and feature maps: Evidence from withindimension defined conjunctions. Quarterly Journal of Experimental Psychology, 52A, 679-715.

Peterson, M. S., Belopolsky, A. V., \& Kramer, A. F. (2003). Contingent visual marking by transients. Perception \& Psychophysics, 65, 695-710.

PosNer, M. I. (1980). Orienting of attention. Quarterly Journal of Experimental Psychology, 32, 3-25.

Pratt, J., Theeuwes, J., \& DonK, M. (2007). Offsets and prioritizing the selection of new elements in search displays: More evidence for attentional capture in the preview effect. Visual Cognition, 15, 133-148.

RAUSCHENBERGER, R. (2003). When something old becomes something new: Spatiotemporal object continuity and attentional capture. Journal of Experimental Psychology: Human Perception \& Performance, 29, 600-615

Theeuwes, J., Kramer, A. F., \& Atchley, P. (1998). Visual marking of old objects. Psychonomic Bulletin \& Review, 5, 130-134.

Treisman, A. M., \& Gelade, G. (1980). A feature-integration theory of attention. Cognitive Psychology, 12, 97-136.

WATSON, D. G. (2001). Visual marking in moving displays: Feature-based inhibition is not necessary. Perception \& Psychophysics, 63, 74-84.
Watson, D. G., \& HuMPhreYs, G. W. (1997). Visual marking: Prioritizing selection for new objects by top-down attentional inhibition of old objects. Psychological Review, 104, 90-122.

Watson, D. G., \& Humphreys, G. W. (1998). Visual marking of moving objects: A role for top-down feature-based inhibition in selection. Journal of Experimental Psychology: Human Perception \& Performance, 24, 946-962.

Watson, D. G., \& Humphreys, G. W. (2000). Visual marking: Evidence for inhibition using a probe-dot detection paradigm. Perception \& Psychophysics, 62, 471-481.

WATSON, D. G., \& HuMPhreYs, G. W. (2002). Visual marking and visual change. Journal of Experimental Psychology: Human Perception \& Performance, 28, 379-395.

Watson, D. G., \& Humphreys, G. W. (2005). Visual marking: The effects of irrelevant changes on preview search. Perception \& Psychophysics, 67, 418-434.

Watson, D. G., Humphreys, G. W., \& Olivers, C. N. L. (2003). Visual marking: Using time in visual selection. Trends in Cognitive Sciences, 7, 180-186.

Watson, D. G., \& Inglis, M. (2007). Eye movements and time-based selection: Where do the eyes go in preview search? Psychonomic Bulletin \& Review, 14, 852-857.

WATSON, D. G., \& MAYLOR, E. A. (2002). Aging and visual marking: Selective deficits for moving stimuli. Psychology \& Aging, 17, 321339.

Wolfe, J. M. (1998). Visual search. In H. Pashler (Ed.), Attention (pp. 13-73). Hove, U.K.: Psychology Press.

Yantis, S., \& Hillstrom, A. P. (1994). Stimulus-driven attentional capture: Evidence from equiluminant visual objects. Journal of Experimental Psychology: Human Perception \& Performance, 20, 95-107.

YANTIS, S., \& Johnson, D. N. (1990). Mechanisms of attentional priority. Journal of Experimental Psychology: Human Perception \& Performance, 16, 812-825.

YANTIS, S., \& JonES, E. (1991). Mechanisms of attentional selection: Temporally modulated priority tags. Perception \& Psychophysics, 50, 166-178.

Yantis, S., \& Jonides, J. (1984). Abrupt visual onsets and selective attention: Evidence from visual search. Journal of Experimental Psychology: Human Perception \& Performance, 10, 601-621.

Yantis, S., \& Jonides, J. (1990). Abrupt visual onsets and selective attention: Voluntary versus automatic allocation. Journal of Experimental Psychology: Human Perception \& Performance, 16, 121-134.

\section{NOTES}

1. Donk and Verburg (2004) suggested that this relatively long time course does not hold when the old items are isoluminant. However, Donk and Verburg employed displays containing both items that were isoluminant with their background and items that arrived with an onset. Their findings were based on the assumption that both sets of items would compete equally at short SOAs, an assumption that does not hold (Braithwaite, Humphreys, Watson, \& Hulleman, 2005). Humphreys, Olivers, and Braithwaite (2006) showed that a long time course held even when old items were not defined by a constant onset.

2. Our color and luminance measurements were obtained from solid patches of color using a Minolta CS-1000 spectroradiometer. As in Rauschenberger (2003), the stimuli were then created using the resulting RGB values.

3. It is extremely unlikely that the lack of a preview benefit here (or in the next experiment) was due to the types of monochromatic stimuli we used; here, numerous researchers have demonstrated robust preview effects with heterogeneous letter stimuli (e.g., Belopolsky, Peterson, \& Kramer, 2005; Donk \& Verburg, 2004; Hodsoll \& Humphreys, 2005; Jacobsen, Humphreys, Schröger, \& Roeber, 2002; Kramer \& Atchley, 2000; Olivers, Humphreys, Heinke, \& Cooper, 2002; Olivers, Smith, Matthews, \& Humphreys, 2005; Peterson, Belopolsky, \& Kramer, 2003; Theeuwes, Kramer, \& Atchley, 1998)

4. As with heterogeneous letter stimuli, there have been many demonstrations of a robust preview benefit with rotated " $\mathrm{T}$ " stimuli (e.g., Olivers et al., 1999).

(Manuscript received February 26, 2008; revision accepted for publication June 10, 2008.) 